\title{
Studi Persepsi Tentang Zakat Perniagaan di Kalangan Pengusaha Batik di Kota Sungai Penuh
}

\author{
Susi Susanti ${ }^{1}$, Ali Hamzah2, dan Maila Sari ${ }^{3}$ \\ 1,2,3 Institut Agama Islam Negeri (IAIN) Kerinci \\ e-mail: susisusanti@iainkerinci.ac.id
}

\begin{abstract}
ABSTRAK. Artikel ini bertujuan untuk menggambarkan Pengetahuan masyarakat tentang zakat perniagaan terutama di kalangan pengusaha batik di Kota Sungai Penuh . Penelitian ini menggunakan metode penelitian deskriptif kualitatif yang mengkaji tentang hukum zakat perdagangan dalam Islam yang mengarah pada pemahaman pengusaha batik tentang zakat perniagaan serta kendala yang dihadapi leh para pengusaha batik terhadap zakat perniagaan. Temuan penelitian ini bahwa Persepsi masyarakat khususnya para pengusaha batik di Kota Sungai Penuh masih sangat minim, bahkan ada di antara mereka yang sama sekali tidak mengetahui apa itu zakat perniagaan dan cara perhitungan zakat perniagaan jika sudah mencapai nisabnya. Kendala atau hambatan yang dialami oleh masyarakat adalah: (a) kurangnya pengetahuan tentang zakat, (b) kurangnya kesadaran akan pentingnya membayar zakat perniagaan atas usaha yang dijalaninya.
\end{abstract}

ABSTRACT. This article aims to illustrate the knowledge of the public business zakat especially among batik entrepreneurs in Sungai Penuh city. This research employs a qualitative descriptive research method that examines the law of trade zakat in Islam that leads to the understanding of batik entrepreneurs about the zakat of business and the obstacles faced. The findings of this research show that the perception of society especially the batik entrepreneurs in Sungai Penuh city is still very low, even among those who do not know what is zakat business and the way of calculating business zakat if it has reached its limit (nisab). Obstacles experienced by the community are: (a) lack of knowledge about zakat, (b) lack of awareness of the importance of paying business zakat for the efforts it has.

Kata kunci: persepsi, zakat, perniagaan, pengusaha batik

\section{PENDAHULUAN}

Zakat merupakan kewajiban setiap muslim. Zakat merupakan rukun Islam yang ke-4 dan menjadi unsur pokok dalam penegakan syariat Islam. Zakat adalah harta tertentu yang wajib dikeluarkan oleh orang beragam Islam dan diberikan kepada golongan yang berhak menerimanya seperti fakir miskin dan semacamnya, sesuai yang ditetapkan oleh syariah. Kata zakat mempunyai beberapa arti, yaitu al- barakatu 'keberkahan', alnamaa 'pertumbuhan dan perkembangan', ath- thaharah ' kesucian', dan ashshalat 'keberesan', dan berarti juga tazkiyah, tathhier mensucikan (Ash Shiddieqy, 1999). Setiap muslim yang telah mencapai nisabnya wajib mengeluarkan zakat. Baik itu zakat fitrah yang dikeluarkan setiap bulan ramadhan, zakat mal, ataupun zakat perniagaan.

Berbicara tentang zakat perniagaan, mungkin tidak banyak diantara kita yang mengetahuinya. Bahkan banyak diantara kita yang beranggapan bahwa zakat perniagaan sama dengan zakat mal. Dalam Islam zakat mal dan zakat perniagaan berbeda. Zakat perniagaan 
adalah zakat yang dikeluarkan dari harta niaga, besarnya 2,5\% dikeluarkan setelah dikurangi utang. Dalam Islam zakat perniagaan dinamakan zakat tijarah adalah zakat yang dikeluarkan atas kepemilikan harata yang diperuntukkan untuk jual-beli. Zakat ini dikenakan kepada perniagaan yang diusahakan baik secara perorangan maupun perserikatan. (CV, PT, Koperasi dan sebagainya). Adapun dalil zakat perniagaan seperti yang disebutkan dalam Al-Quran Surat An$\operatorname{Nur}(24): 37$

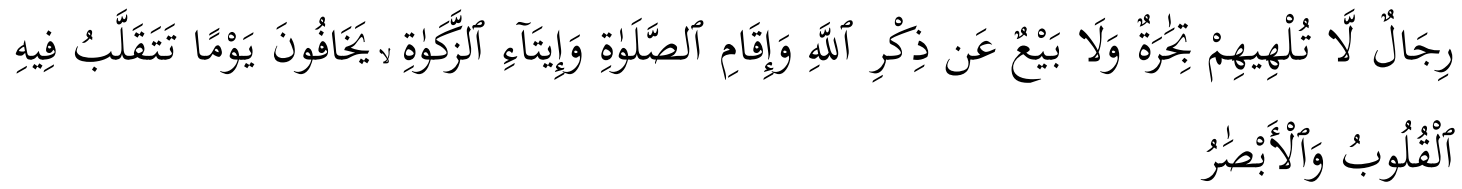

"Orang yang tidak dilalaikan oleh perdagangan dan jual beli dari mengingat Allah, melaksanakan salat, dan menunaikan zakat. Mereka takut kepada hari ketika hati dan penglihatan menjadi guncang (bari Kiamat)"

Adapun Hadist yang mendasari kewajiban menunaikan zakat ini adalah:

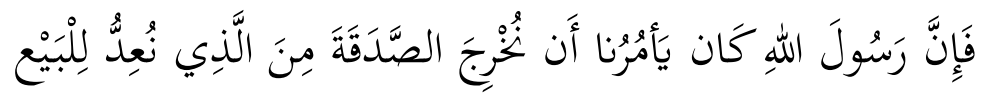

"Rasulluloh SAW memerintabkan kami agar mengeluarkan zakat dari semua yang kami persiapkan untuk berdagang "(HR. Abu Dawud).

Berdasarkan ayat dan hadist di atas, jelaslah bahwa zakat perniagaan merupakan zakat yang wajib dikeluarkan oleh setiap muslim yang melakukan perniagaan dengan maksud untuk mencari laba. Namun sayangnya banyak diantara kita yang kurang mengetahui zakat ini.

Di Indonesia banyak didirikan perusahan-perusahan baik dalam bentuk skala besar ataupun usaha kecil (usaha rumahan). Tak terkecuali di Kota Sungai Penuh, yang merupakan pusat kegiatan perekonomian di Kota Sungai Penuh dan Kerinci, banyak didirikan bentuk bentuk usaha perniagan baik yang berbentuk CV, PT, koperasi, ataupun usaha kecil (usaha rumahan), salah satunya adalah usaha batik.

Berdasarkan permasalahan diatas, dibutuhkan sebuah solusi atas masalah tersebut. Perlu adanya sosialiasi kepada masyarakat khususnya bagi para pengusaha di Kota Sungai Penuh tentang wajibnya mengeluarkan zakat perniagaan, dan cara perhitungan zakat perniagaan tersebut. karena itulah mendorong penulis melakukan kajian secara khusus terhadap persepsi masyarakat pengusaha batik terhadap zakat perniagaan. Adapun rumusan masalah dalam penelitian ini adalah: 1. Bagaimana persepsi masyarakat Kota Sungai Penuh tentang zakat perniagaan, 2. Apa kendala dan solusi yang dihadapi pengusaha batik di Kota Sungai Penuh terkait dengan zakat perniagaan.

\section{METODOLOGI}

Jenis penelitian ini adalah deskriptif kualitatif, yaitu penelitian yang mendeskripsikan atau memberi gambaran terhadap objek yang diteliti sebagai sumber langsung dan instrument peneliti sendiri, yaitu penelitian merupakan perencanaan, pelaksanaan pengumpulan data, analisis, penafsiran data, dan apada akhirnya ia menjadi laporan hasil penelitian. Jenis penelitian yang dilakukan adalah penelitian lapangan (field research), yang bersifat deskriptif yaitu menggambarkan dan mengumpulkan informasi mengenai keadaan objek yang diteliti sebagaimana adanya sesuai dengan data yang diperoleh di lapangan. Sumber data dalam penelitian ini adalah: Data primer 
para pengusaha batik di Kota Sungai Penuh . Data ini berupa data wawancara. Data sekunder data ini berupa dokumentasi penting menyangkut data-data perhitungan zakat profesi.

\section{TEMUAN}

Berdasarkan hasil observasi yang peneliti lakukan, diperoleh informasi bahwa di Kota Sungai Penuh terdapat 5 usaha batik yang dikelola secara kelompok oleh masyarakat sungai penuh. Kelima usaha batik tersebut berlokasi di Kota Sungai Penuh, rawang dan pondok tinggi. Berdasakan hasil wawancara, diperoleh juga informasi bahwa banyak diantara mereka yang selama bergelut dengan usaha tersebut belum pernah mengeluarkan zakat perniagaan.

Alasannya, dikarenaka kurangnya pengetahuan mereka terhadap zakat perniagaan, dan tentang cara perhitungan zakat tersebut. Namun mereka mengaku bahwa mereka selalu mengeluarkan zakat setiap tahun, yaitu zakat fitrah. Jika dilihat dari buku besar pendapatan dan pengeluaran masing-masing usaha batik tersebut diketahui bahwa rata-rata keuntungan yang mereka peroleh setiap bulan adalah RP.3.000.000,00.

Berarti jika dihitung dalam setahun mereka mendapat keuntungan 36.000.000 per tahun. Jika dilihat dari nominalnya, mereka wajib mengeluarkan zakat perniagaan atas usaha mereka tersebut. Namun kenyataannya itu tidak mereka lakukan.

Salah satu faktor yang menyebabkan mereka tidak mengeluarkan zakat perniagaan dikarenakan kurangnya pengetahuan mereka tentang zakat perniagaan dan cara perhitungan untuk zakat perniagaan. Selama ini mereka menganggap bahwa zakat fitrah sama dengan zakat perniagaan. Padahal anatara zakat ftrah dan zakat perniagaan adalah dua hal yang berbeda. Zakat fitrah adalah zakat yang wajib dikeluarkan oleh umat Muslim ketika bulan suci ramadhan, sedangkan zakat perniagaan adalah zakat yang dikeluarkan oleh pengusaha yang melakukan perniagaan dan telah mencapai nisabnya.

\section{DISKUSI}

Para ulama banyak memberikan defenisi zakat antara satu dengan yang lain berbeda akan tetapi memiliki fokus yang sama, diantaranya: Menurut Mohd Rafi'i Zakat adalah mengeluarkan sebagian dari harta benda atas perintah Allah, sebagai shadaqah wajib kepada mereka yang telah ditetapkan menurut syarat-syarat yang telah ditentukan oleh hukum Islam. (Rafi'i, 1978, 346). Zakat adalah memberi suatu bagian dari harta yang sudah mencapai nisab kepada orang fakir dan sebagainya, yang tidak bersifat dengan suatu halamgam syara' yang tidak membolehkan kita memberikan kepadanya. (As-Saukani dalam Ash-Shiddieqy, 2009, 5).

Zakat menurut mazhab Maliki ialah mengeluarkan sebagian harta yang khusus dari harta yang khusus pula yang telah mencapai nishab (batas kuantitas yang mewajibkan zakat) kepada orang yang berhak menerimanya (mustahiqq). Dengan catatan, kepemilikan itu penuh dan mencapai hawl (setahun). Sedangkan Zakat menurut mazhab Hanafi ialah menjadikan sebagian harta yang khusus dari harta yang khusus sebagai milik orang yang khusus. Zakat menurut mazhab Syafi'i ialah sebuah ungkapan untuk keluarnya harta atau tubuh sesuai dengan cara khusus. Zakat menurut mazhab Hambali ialah hak yang wajib dikeluarkan dari harta yang khusus untuk kelompok yang khusus pula.( Al-Zuhayly, 2008, 83).

Sedangkan pengertian Zakat profesi terdiri dari dua kata yaitu zakat dan profesi. Dalam literatur fiqh klasik pengertian zakat adalah hak yang dikeluarkan dari harta atau badan. 
Sehubungan dengan hal ini, Wahbah al-Zuhayly mengemukakan bahwa zakat adalah penuanaian hak yang wajib yang terdapat dalam harta. Dalam kamus Bahasa Indonesia, profesi adalah bidang pekerjaan yang dilandasi pendidikan keahlian (keterampilan, kejujuran, dan sebagainya) tertentu. Zakat profesi adalah zakat yang di keluarkan dari hasil apa yang di peroleh dari pekerjaan dan profesinya.

Penulis kitab Al-Mughni mengatakan "suatu barang belum dapat dikatakan sebagai barang perniagaan, kecuali memenuhi dua syarat berikut ini: pertama, barang itu diperoleh melalui usaha seperti jual beli, pernikahan, perceraian, hibah, wasiat, harta rampasan perang, dan usaha-usaha lainnya. Sebab apa yang tidak ditetapkan baginya hukum zakat melalui kepemilikan tersebut, maka tidak cukup hanya sekedar dengan niat saja, sebagaimana halnya puasa. kedua, berniat ketika hendak memilikinya sebagai barang perniagaan, jika tidak diniati sebagai barang perniagaan, bearti barang itu bukan sbagai barang perniagaan, meski diniati setelah kepemilikannya. jika memperoleh kepemilikan barang itu melalui warisan, lalu dimaksudkan sebagai barang perniagaan, maka barang tersebut tidak dapat disebut sebagai barang perniagaan. karena hokum awal pada barang pemberian tersebut adalah pemberian secara Cuma-Cuma. sedangkan barang perniagaan harus diperoleh melalui proses tawar menawar. sehingga warisan itu tidak dapat dikatakan sebagai barang perniagaan hanya dengan niat semata.(Muhammad, 2008, 288-289).

Untuk bisa sampai ke arah sana diperlukan pemahaman yang memadai untuk menyadarkan bahwa kewajiban zakat bukanlah sekedar amaliah ritual mahdhah saja, tetapi juga memiliki makna kewajiban sosial. Zakat adalah kesalehan diri melalui ikhtiar sosial. Agar sampai kepada kesadaran seperti itu diperlukan penyadaran yang dibarengi dengan tindakan amal-amal sosial, termasuk mengeluarkan zakat, infak dan shadaqah. Karena dalam ajaran zakat ini pandangan dan komitmen sosialnya begitu jelas, bahkan dari titik kepentingan yang paling menyentuh hajat orang banyak, yaitu pemenuhan kebutuhan ekonomi. Secara umum zakat profesi menurut putusan Tarjih Muhammadiyah adalah zakat yang dikeluarkan dari hasil usaha yang halal yang dapat mendatangkan hasil atau uang, relatif banyak dengan cara yang halal dan mudah, baik melalui keahlian tertentu maupun tidak. Sedangkan dalam pemahaman Zamzami Ahmad, zakat profesi adalah zakat penghasilan yang didapat dan diterima dengan jalan yang halal dalam bentuk upah, honor ataupun gaji. (Inoed,, 2005 : 50).

Mayoritas ulama dari kalangan para sahabat, tabi'in dan para ulama yang hidup sesudahnya, mewajibkan zakat atas barang perniagaan. sedangkan abu Hanifah, Imam Malik dan Imam Asy Syafi'I secara tegas mewajibkan zakat atas barang perniagaan. Mereka berlandaskan pada hadist dari Samrah bin Jundub dimana dia menceritakan: "sesungguhnya Rasulullah SAW memerintahkan kita untuk mengeluarkan zakat dari barang yang disediakan untuk dijual. "HR. Abu Dawud, Daruqutni, al Bagawi dan Suyuthi”.

Ibnu Hazm mengatakan: "bahwa Abdurahman bin Abdul Qari' pernah menangani baitul mal pada masa kepemimpinan Umar bin Khathtab. jika pergi keluar Atha selalu mengumpulkan kekayaan para pedagang dan menghitungnya, baik yang terlihat secara materil maupun yang tidak terlihat". dari Abu Amr bin Hammas, dari ayahnya ia menceritakan: "aku pernah menjulan kulit dan jinfan (mangkuk besar) Tiba-tiba Umar bin Khathtab berjalan melewati aku seraya berkata: tunaikan zakat hartamu! akupun menjawab: wahai Amirul Mukminnin, sesungguhnya ini hanyalah kulit. selajutnya umar berkata: Tentukan harganya, kemudian keluarkanlah zakatnya" (HR. Asy Syafi'i, Imam Ahmad dan Daruqutni). dalam kitab al-Mughni Ibnu Hazm mengatakan "riwayat ini sudah cukup popular dan tidak ditolak, sehingga 
dijadikan sebagai ijma'." Sedangkan didalam kitab Al-Mannar, Jumhur ulama mewajibkan zakat atas barang perniagaan. adapun ulama. Zahiriyah berpendapat "tidak ada zakat atas barang perniagaan”. kapan suatu barang menjadi barang perniagaan. (Muhammad, 2008, 288-289).

Temuan tentang reorientasi tentang zakat perniagaan oleh (Badruddin, 2011) zakat perniagaan merupakan zakat yang iwajibkan terhadap para pedagang yang menjalankan aktifitas perdagangan dari modal yang dikembangkan dan mendapat keuntungan dari itu. keuntungan dari perdagangan ini telah diklasifikasikan sebagai harta yang wajib dijadikan sebagai zakat perniagaan.

Kedua, Pemahaman pedagang tentang zakat perdagangan di pasar Lakesi kota ParePare, oleh (Nurjannah, 2017), pemahaman masyarakat pedagang tentang zakat masih kurang, baik berupa syarat, nisab, haul dan hal lainnya yang berkaitan dengan zakat perniagaan dikarenakan beberapa factor. Ketiga, Zakat profesi zakat penghasilan menurut hokum Islam, oleh (Marimin,dkk, 2015), zakat Pofesi itu hukumnya wajib sama dengan zakat usaha dan penghasilan lainnya seperti pertanian, perternakan, dan perdagangan, batas nisabnya sama dengan batas nisab hasil tanaman yaitu $5 \%$.

Dalam Islam zakat dibebankan kepada orang yang mampu. Zakat merupakan kewajiban bagi seluruh umat Islam tanpa terkecuali jika sudah mencapai nisabnya. Oleh karena itu, masyarakat harus memiliki pengetahuan tentang jenis-jenis zakat yang harus dikeluarkan. Karna selama ini masyarakat hanya tau tentang zakat fitrah dan zakat mal saja. Sedangkan ada zakat lain wajib dikeluarkan oleh mereka yang memiliki usaha baik perseorangan ataupun kelompok yaitu zakat perniagaan. Namun sayangnya zakat perniagaan tidak terlalu populer dan dikenal oleh masyarakat terutama mereka yang memiliki sebuah usaha.

Zakat perniagaan atau dalam Islam dikenal dengan zakat tijarah adalah zakat atas kepemilikan harta yang diperuntukkan untuk jual-beli. Zakatini dikenakan kepada perniagaan yang diusahakan baik secara perorangan maupun perserikatan (CV, PT, Koperasi dan sebagainya). Pada badan usaha yang berbentuk serikat (kerjasama), maka jika semua anggota serikat tersebut beragama Islam, zakat dikeluarkan lebih dulu sebelum dibagikan kepada pihak-pihak yang berserikat. Tetapi jika anggota serikat terdapat orang yang non muslim, maka zakat hanya dikeluarkan dari anggota serikat muslim saja (apabila jumlahnya lebih dari nisab. Zakat perniagaan berlaku pada seseorang bila memenuhi dua kriteria: telah mencapai nishab (senilai 85 gram emas), Kadarnya zakatnya adalah sebesar 2,5\%, Dapat dibayar dengan uang atau barang. Di Kota Sungai Penuh terdapat usaha yang cukup berkembang yaitu usaha batik tulis dan batik cap.

Usaha batik adalah salah satu usaha kecil yang cukup berkembang di Kota Sungai Penuh . Sejak tahun 2016 sampai sekarang terhitung sudah terdapat 5 rumah produksi yang memproduksi batik tulis maupun batik cap, diantaranya adalah rumah batik incung dan batik incoang yang berlokasi di larik pantai, batik Pandan Mengurai di pondok tinggi, Batik Karang Setio di rio jayo, dan Batik Daun Sirih di rawang. masing-masing batik tersebut memiliki ciri khas yang membedakan antara batik yang satu dengan yang lainnya. Agar usaha batik ini terus mengalami perkembangan, pemerintah dinas tenaga kerja terus memberikan pelatihan-pelatihan kepada pengrajin batik tersebut serta memberikan bantuan yang mereka butuhkan.

Berdasarkan hasil observasi yang peneliti lakukan, diperoleh informasi bahwa pendapatan rata-rata pengrajin batik tersebut adalah Rp 5.000.000 -10.000.000/ Bulan. Jika dilihat nominalnya jumlah pendapatan yang mereka dapatkan, sudah seharusnya mereka mengeluarkan zakat yang disebut dengan zakat perniagaan. Namun, kenyataannnya mereka tidak 
mengeluarkan zakat perniagaanqw atas usaha mereka diakrenakan kekurangtahuan mereka tentang zakat perniagaan. Hal ini diperkuat dari hasil wawancara yang peneliti lakukan kepada 6 pengrajin batik, Berdasarkan hasil wawancara tersebut, dapat disimpulkan bahwa masih rendahnya pengetahuan para pengrajin batik di Kota Sungai Penuh tentang kewajiban mengeluarkan zakat perniagaan.

Dari 5 orang hanya 1 orang yang mengeluarkan zakat perniagaan dan mengetahui cara mengeluarkan zakat perniagaan, selebihnya sama sekali belum pernah mengeluarkan zakat perniagaan tersebut karena tidak memiliki pengetahuan tentang zakat perniagaan. Padahal sebagaimana yang kita ketahui zakat perniagaan adalah zakat yang wajib dikeluarkan oleh masyarakat yang memiliki usaha skala kecil maupun usaha dalam skala menengah dan skala atas. Zakat perniagaan dikeluarkan setiap tahun sebesar 2,5\%.

Para pengusaha batik di Kota Sungai Penuh, tidak pernah membayarkan zakat perniagaan dari usaha yang mereka dirikan. Penyebabnya adalah kurangnya pemahaman dari masyarakat khususnya yang memiliki usaha atau bisnis tentang apa yang dimaksud dengan zakat perniagaan dan cara mengeluarkannya. Para pengusaha batik tersebut tidak mengetahui kapan mereka harus mengeluarkan zakat perniagaan, dan berapa kadar zakat yang harus dikeluarkan termasuk nisabnya.

Selama ini, mereka hanya mengetahui tentang zakat mal dan zakat fitrah. Zakat mal adalah zakat terhadap harta yang wajib dikeluarkan oleh pemiliknya jika sudah mencapai nisabnya. Sedangkan zakat perniagaan adalah zakat atas usaha yang dimiliki oleh seseorang tersebut. Selama ini mereka mengganggap bahwa zakat mal adalah zakat perniagaan, padahal jelas bahwa zakat mal dan zakat perniagaan adalah berbeda. Kurangnya pengetahuan mereka terhadap zakat perniagaan, wajar jika mereka sama sekali belum pernah mngeluarkan zakat perniagaan atas usaha mereka tersebut.

Selain itu kurangnya pengetahuan para pengrajin batik tentang zakat perniagaan dikarenakan tidak ada sosialisasi tentang zakat perniagaan baik dalam bentuk seminar ataupun workshop yang dilakukan oleh baitul mal sebagai pengelola zakat. Baitul mal sebagai pengelola zakat dapat mensosialisasikan tentang zakat-zakat yang wajib dikeluarkan sebagai seorang muslim, salah satunya adalah zakay mal. Sosialisasi yang paling mudah dilakukan adalah dengan saling sharing untuk menambah wawasan dan ilmu baru bagi masyarakat khususnya bagi yang memiliki usaha ataupun bisnis, agar pengethauan mereka tentang zakat menjadi luas. Kurangnya sosialisai tentang zakat kepada masyarakat berdampak pada kurangnya pengetahuan masyarakat tentang apa itu zakat perniagaan, cara perhitungannya dan kapan jatuh nisabnya. Berdasarkan hasil wawancara yang dilakukan terlihat bahwa para pengrajin batik Kota Sungai Penuh sama sekali tidak memahami tentang zakat perniagaan. Mereka hanya mengerti tentang zakat mal dan zakat fitrah yang selalu mereka keluarkan selama bulan ramadhan.

Kendala adalah sesuatu yang menjadi halangan atau rintangan bagi seseorang dalam melakukan sesuatu. Kendala juga diartika sebagai suatu keadaan yang membatasi, menghalangi, atau mencegah pencapaian sasaran; kekuatan yang memaksa pembatalan pelaksanaan. Dalam melaksanakan zakat perniagaan ada beberapa kendala yang dihadapi oleh para pengusaha batik di Kota Sungai Penuh. Kendala tersebut tergambar ketika peneliti melakukan wawancara kepada para pengusaha batik tersebut.

Berdasarkan hasil wawancara yang peneliti lakukan kepada 5 informan yang berfrofesi sebagai pengusaha batik. Diperoleh informasi bahwa adapun kendala yang dihadapi terkait dengan zakat perniagaan adalah: 
1. Kurangnya kesadaran masyarakat untuk menunaikan kewajiban membayar zakat perniagaan.

2. Kurangnya pengetahuan masyarakat tentang bagaimana cara perhitungan zakat perniagaan

3. Kurangnya pengetahuan mereka tentang cara penyaluran zakat perniagaan

4. Kurangnya sosialisasi tentang zakat perniagaan di kalangan pengusaha batik di Kota Sungai Penuh .

\section{DAFTAR PUSTAKA}

Abidin, Zainal, 1951, Kunci Ibadah, Semarang: Toha Putra

Al-Asqalani, Ibnu Hajar, 2013, Buluhgul Maram Dan Dalil-DaliI Hukum, Jakarta: Gema Insani

Al-Jaza’iri, Syaikh Abu Bakar Jabir, 2016, Minhajul Muslim Konsep Kehidupan Ideal Dalam Islam, Cet-Ke XV, Jakarata: Darul Haq.

Al-Zuhayly, Wahbah 2008, Zakat Kajian Berbagai Mazhab, Bandung: Remaja Rosda Karya.

Ash-Shiddieqy, Hasby, 2009, Pedoman Zakat, Semarang: Pustaka Rizki Putra.

Badruddin.Munawar, 2011, Jurnal Media syari'ah, vol XIII No.2.

Hafifuddin, Didin, 1998, Panduan Praktis Tentang Zakat Infak Dan Sedekah, Jakarta: Gema Insani.

Hasan, Ali, 2001, Tuntunan Puasa dan Zakat. Jakarta: PT.Raja Grafindo Persada.

Kementerian Agama RI, ,2013, Buku saku menghitung zakat, Jakarta: Kementerian Agama RI

Mahmud, Abdul Al-Hamid, 2006, Ekonomi Zakat Sebuah Kajian Moneter Dan Keuangan Syari’ah, Jakarta: Raja Grafindo Persada.

Marimin. Agus, 2015, Jurnal Ekonomi Islam, Vol I, No.1.

Muhammad, Kamil, 2008, Fiqh Wanita,Jakarta: pustaka al-Kausar.

Mursydi, 2003, Akuntansi Zakat Kontemporer, Bandung: Raja Grafindo Persada Karya.

Mustafa Bid Al-Bugha, t.t, Fikih Islam Lengkap Penjelasan Hukum-Hukm Mazhab Syafi'I, Jakarta: Gema Insani.

Nurjannah, 2017, Pemahaman pedagang tentang zakat perdagangan di pasar Lakesi kota ParePare.

Restu Ilahi Inoed, Amiruddin, dkk. 2005. Anatomi fiqh Zakat. Yogyakarta: Pustaka Pelajar

Rifai, Mohd 1978 Ilmu Fiqih Islam Lengkap, Semarang: Toha Putra.

Sabiq, Sayyid t.t, Fikih Sunnah I, Jakarta: Pena Pundi Aksara.

Syarifuddin. Amir, 1987, Pembaharuan Pemikiran Dalam Hukum Islam. Jakarta: Logos.

Yasin, Ahmad Hadi, 2012, Panduan Zakat Praktis, Jakarta: Dompet Dhuafa Republika.

Yusuf Qardlawi. 1996. Fiqhuz-Zakat, Terj. Didin Hafidhuddin, et.al., Bogor: Pustaka Litera Antar Nusa. 